\title{
Evaluation of Analgesic And Anti-inflammatory Activity of Herbal Formulation Used for Mastitis in Animals
}

\author{
Ranjith, D.*, Nisha, A.R., Nair, S.N., Maria Litty, Muhsina Rahman and Juliet, S. \\ Department of Veterinary Pharmacology and Toxicology, College of Veterinary and Animal Sciences, Pookode, Wayanad, \\ Kerala, India
}

Corresponding author: ranjith946@gmail.com

\begin{abstract}
Nature has been the source of medicinal agents for more than thousands of years, interestingly phytotherapy dominates in age old traditional system and also practice of alternative medicine across different cultures as Indian and Chinese system of medicine and Unani literature respectively. More than $70 \%$ of world's population is rely on herbal medicines for most part of their primary health care system. Investigations have been carried out from time to time to develop types of herbal formulations either singly or in combinations (Polyherbal formulations) to enhance overall therapeutic potential of the formulation. The present study was carried out to ascertain analgesic and anti-inflammatory activities of methanolic extracts of herbal combination containing equal proportion of Diploclisia glaucescens leaf and rhizomes of Curcuma longa in Wistar albino rats. The solvent yield of these extract was $16.75 \%$ and colour with dark brown to reddish brown with solid to semisolid consistency. The collected extracts were subjected to phytochemical analysis before animal experimentation, revealed the presence of all major phytoconstituents including alkaloids, flavonoids, saponins, glycosides, tannins and terpene compounds. The analgesic activity was assessed by Eddy's hot plate method and Formalin induced rat paw edema model and anti-inflammatory activity by Carrageenan induced paw edema model respectively. Significant analgesic and anti-inflammatory activity was noticed in the herbal formulation treated groups of both 200 and $400 \mathrm{mg} / \mathrm{kg}$ body weight. These test drug activity was sustained and comparable to the standard drug, Ibuprofen and Indomethacin. Thus the study can be concluded that the test drug possess significantly higher analgesic and anti-inflammatory activity possibly due to the presence of manifold secondary phytoconstituents.
\end{abstract}

Keywords: Polyherbal formulation, analgesic, anti-inflammatory activity, Diploclisia glaucescens, Curcuma longa

India witnessed a remarkable growth in production and consumption of milk and dairy products in recent years, which is emerged as important global food. India is the largest producer of milk with $16 \%$ global 
production $^{(1)}$. Bovine mastitis in dairy cattle is the most devastating inflammatory reaction of udder tissues caused by invasion of bacteria. Mastitis affects the entire dairy industries badly throughout the world $^{(2)}$ and is the major cause of economic loss to the dairy industry and its prevalence is aprime factors in determining farm probability. Reduced milk yield due to mastitis has been estimated throughout the literature to be the largest source of loss due to an occurrence of mastitis in dairy cattle ${ }^{(3)}$. The economic losses due to mastitis in United States, UK, India and Worldwide has been estimated at \$2 billion ${ }^{(2)}$, \$3.71 million, $\$ 1.1$ billion (4) and $\$ 35$ billion $^{(5,6)}$ respectively. Among the animal diseases which affect the profitability of rearing, mastitis is considered to be one of theexpensive diseases in terms of production $\operatorname{losses}^{(7,8)}$ and National Mastitis Council, a global organization for mastitis control and milk quality, estimates milk yield loss to be 70 percent of total mastitis costs ${ }^{(9)}$. Milk loss due to mastitis results in an average milk yield loss per cow of $0-9 \%$ in the first lactation and approximately $0-11 \%$ in the second lactations and beyond ${ }^{(10)}$. Regardless of the precision of this estimate, the magnitude of the loss to the industry is staggering. Predisposing factors formastitis incidence highly depend upon type of breed, stage of lactation, management practices and awareness of the dairy farmers ${ }^{(11)}$. Antibiotics have been used for the treatment of mastitis for more than 50 years and are used at two points, one is to treat outbreaks of mastitis in lactating cows and second is dry cow therapy employed to reduce subclinical infections during dry period and to prevent new infection during early lactation period ${ }^{(12)}$. In current scenario, antimicrobial investigations revealed the isolated mastitis pathogens were resistant to multifarious antibiotics including pencillin, clindamycin and cefotaxime ${ }^{(13)}$. Therefore, there is a need to explore alternative approaches for the treatment of mastitis. This research work focus on the use of herbal mixture used in the treatment of bovine mastitis and highlights their importance as an alternative natural product therapeutic resource ${ }^{(14)}$.

Herbal treatments have been found to be as effective as conventional antibiotics in some situations for treating or preventing mastitis in dairy cattle. The herbal remedies contain ingredients that serve as antibacterial and strong anti-inflammatory agents ${ }^{(15)}$. The present study makes an attempt to unravel the analgesics and anti-inflammatory activity of herbal formulation used for the mastitis in animal by the locals of Wayanad districts of Kerala. The herbal formulation contains a combination of Diploclisia glaucescens leaves and rhizomes of Curcuma longa at equal ratio.

Diploclisia glaucescens (Blume) Diels is a deciduous climbing shrub belongs to the family Menispermaceae, commonly occurs in moist and semi evergreen forests up to $1500 \mathrm{~m}$ and distributed in India, Sri Lanka, southern China and Southeast Asia ${ }^{(16)}$. The leaf extract is given to drink frequently among Tanchangyas for rapid cure from diarrhoea in Rangamati (Bangladesh). Powdered leaf with milk given in biliousness, gonorrhea and syphilis and the stem of this plant used in diabetes, kidney stone and asthma in India. The genus Diploclisia belonging to tribe Menispermae contains a good quantity of benzylisoquinolines ${ }^{(17)}$. The studies on seeds, root and stem of $D$. glaucescens reported isolation of 20- Hydroxyecdysone as major constituent along with proaporphine alkaloid stepharine, triterpinoids serjanic acid, phytolaccagenic acid and their glycosides ${ }^{(18)}$.

Ethno medically, Diploclisia glaucescens plant leaves along with gingelly oiland coconut (Cocos nucifera) oil $100 \mathrm{ml}$ each is heated and applied externally for sprain. Turmeric (Curcuma longa Linn) is extensively used as a spice and grown widely throughout Indian subcontinent. Turmeric plant has been used in traditional medicine as a remedy for various diseases including cough, diabetes and hepatic disorders. For the last few decades, extensive works have been done to establish the pharmacological actions of turmeric and its extracts ${ }^{(19)}$. Several medical properties have been attributed to Curcuma longa Linn. Rhizome 
and has been used by medical practitioners as an anti-diabetic ${ }^{(2,3,20,21-23)}$, hypolipidemic ${ }^{(2,3,20,24,25-27)}$, antiinflammatory ${ }^{(2,24,27)}$, anti-diarrhoeal ${ }^{[24]}$, hepatoprotective ${ }^{[23,24]}$, anti-asthmatic ${ }^{[2,27]}$ and anti-cancerous drug.

\section{MATERIALS AND METHODS}

Collection and Identification of Plant materials: The matured fresh leaves of Diploclisia glaucascens and rhizomes of Curcuma longa were collected from the outfield of Wayanad regions of Kerala situation at latitude DMS $11^{\circ} 37^{\prime} 43.34^{\prime}$ N , longitude DMS 76²'52.5'E and elevation of 773.4 Meters (2537.39 Feet). The plant materials were identified and authenticated taxonomically at MS Swaminathan Research Foundation, Puthoorvayal, Wayanad respectively.

Preparation of Methanolic extract: The plant parts were washed with distilled water to remove dirt and soil and cutted in to small pieces and shade dried. The dried materials were powdered and passed through a 60 mesh sieve. The herbal preparation was formulated by mixing equal quantity of Curcuma longa rhizome powder and Diploclisia glaucascens leaves powder respectively. The powdered materials were extracted in a Soxhlet apparatus using methanol as solvent by continuous heat extraction for about 70 hrs. The solvent was removed from the extract in a rotary vacuum evaporator and the extract subsequently dried in an oven at $45{ }^{\circ} \mathrm{C}$ to obtain a solid mass of the crude extract which was kept in $-20^{\circ} \mathrm{C}$ prior to use. For experimental purpose the alcohol extract was prepared in distilled water containing $2 \% \mathrm{v} / \mathrm{v}$ Tween 80 (as a suspending agent).

Animals: For all the experimental purpose Wistar albino rats weighing 150-200 gms were used for the study. The animals were maintained under standards environmental conditions of Temperature, illumination, light and dark cycle. The requisite permission for animal experimentation were duly obtained from Institutional Animal Ethical Committee before commencing of the experiment with no. IAEC/COVAS/PKD/4/2018 dated 13.04.2018.

Determination of percent yield of the plant extract: The extract obtained with the solvent was weighed and the percentage yield was calculated in terms of dried weight of the plant material. The colour and consistency of the extract were also noted. Percentage yield of the plant extract was calculated according to the formula ${ }^{(28)}$. The present study showed an yield of $16.75 \%$.

$\%$ Yield of the extract $=\frac{\text { Final weight of the extract }}{\text { Initial weight of the powder }} \times 100$

Phytochemical analysis: The extracts and fractions were subjected to qualitative phytochemical tests for alkaloids,tannins flavonoids, saponins,steroids and triterpenoids, amino acids, proteins and carbohydrates adopting the standard procedures ${ }^{(29,30)}$.

Evaluation of Analgesic activity by Hot Plate Method: The central analgesic activity against thermal stimulus was evaluated in rats following hot plate method. Rats were screened for analgesic activity by placing them on Eddy's hot plate maintained at $55 \pm 0.1^{\circ} \mathrm{C}$ and reaction time were recorded in seconds for forepaw licking or jumping. Only rats which reacted within $15 \mathrm{sec}$ and which did not show large variation when tested on four separate occasions, each $20 \mathrm{~min}$ apart, were taken for the test. All the test and standard drugs were administered 1 hour prior to placing the animal in hot plate. The response time was noted as the time at which animals reacted to the pain stimulus either by paw licking or jump response, 
whichever first appeared recorded by a stop-watch. A cutoff period of $30 \mathrm{sec}$ was maintained to avoid damage to the paw. The control group (I) was orally administered distill water at the rate of $10 \mathrm{ml} / \mathrm{kg}$ and standard group (II) receiving $100 \mathrm{mg} / \mathrm{kg}$ p.o. Ibuprofen. Similarly group III and IV were given $200 \mathrm{mg} /$ $\mathrm{kg}$ and $400 \mathrm{mg} / \mathrm{kg}$ of the methanolic extract of herbal formulation consisting of Diploclisia glaucescens leaves and Curcuma longa rhizomesin equal ratio respectively. The drugs or vehicle were administered orally and the reaction time was observed at $0,15,30,60$ and 120 min after drug administration ${ }^{(31-34)}$.

Evaluation of Formalin test to assess the analgesic activity in rats: The formalin-induced paw licking was studied in rats using the method of $(39,40)$. In this method, $100 \mu 1$ of $3 \%$ formalin was injected into the subcutaneous tissue on the plantar surface of the right hind paw of rats one hour after oral administration of the extract @ $200 \mathrm{mg} / \mathrm{kg} \& 400 \mathrm{mg} / \mathrm{kg}$, Indomethacin @ 10mg $/ \mathrm{kg}$ body wt. and distilled water@10 ml/kg. In each rat the pain like behaviour (biting / licking and flinching of the injected paw) were observed as soon as the injection was given (i.e. early phase, $0-5 \mathrm{~min}$ post-injection) and in the late phase (20-30 min post-injection) after injection. The mean of the time spent on licking the injected paw in each group was recorded ${ }^{(35)}$.

Evaluation of Anti-inflammatory activity: A total of 24 animals were selected randomly and divided in to four groups, each group having six animals. The animals were fasted for $24 \mathrm{~h}$ with free access to water prior to experiments. Approximately $100 \mu \mathrm{l}$ of $1 \%$ carrageenan suspension (prepared $1 \mathrm{~h}$ before each experiment) was injected into the plantar surface of the left hind paw of all the four groups of rats $(36,37)$ and the site of injection was marked. Rats of group I (positive control group) received only distilled water, similarly Ibuprofen @ 100 mg/kg body wt, herbal formulation low dose @ 200mg/kg and herbal formulation high dose @ $400 \mathrm{mg} / \mathrm{kg}$ were given orally to animals $1 \mathrm{~h}$ before carrageenan injection as group II, III and IV respectively. The anterio-posterior diameter of the rat paw was measured at $0-6$ hrs in hourly interval and $24 \mathrm{hrs}$ after carrageenan injection using digital micrometer at the marked site. The difference between the basal value of paw diameter and that measured at different time intervals was noted in millimeters and the average increase in paw volume of each group was calculated and compared with the positive control (distilled water) and the indomethacin $\left(10 \mathrm{mg} / \mathrm{kg}\right.$ orally) groups ${ }^{(38-43)}$.

\section{Statistical analysis}

All data were expressed as Mean \pm SEM. The statistical significance was determined using One way Analysis of Variance (ANOVA) followed by the Duncan's Multiple Range test (DMRT). A $p<0.05$ was considered as an indication of a significant difference.

\section{Results and Discussion}

The world health organization (WHO) have listed more than 21,000 species of plants around the world for medicinal purposes. Among them, over 7500 species of plants were estimated to be used by 4365 ethnic communities for human and animal health care in India ${ }^{(44)}$ and about 2500 species of plants belongs to more than 1000 genera being used by indigenous system of medicines ${ }^{(4)}$. Among the plant rich countries, India ranks $10^{\text {th }}$ position of the world and fourth among the Asian countries, the Western and Eastern Ghats harbors about 5,332 endemic species of higher plants ${ }^{(46)}$. There are about twenty five global hotspot has been identified so far, of which Eastern Himalayas and Western Ghats of India have significance ${ }^{(47)}$. The traditional practices of the present combination was successfully used by locals of 
Western Ghats regions of Wayanad district of Kerala for effective treatment of mastitis in animals. The phytochemical analysis of the herbal formulation revealed the presence of all major secondary metabolites viz. alkaloids, flavonoids, glycosides, phenolic compounds, tannins and saponins, the results of the study was supported by others findings ${ }^{(48-53)}$. The results of the preliminary phytochemical screening provide an empirical basis for the use of medicinal plants in traditional therapy. The phytochemical constituents are responsible for the biological and pharmacological actions of these plants. The detailed secondary metabolites and their medicinal properties has been listed in Table 2.

Table 1: Results of Preliminary phytochemical analysis of Methanolic extract of Herbal formulation containing Diploclisia glaucescens leaves and Curcuma longa rhizomes

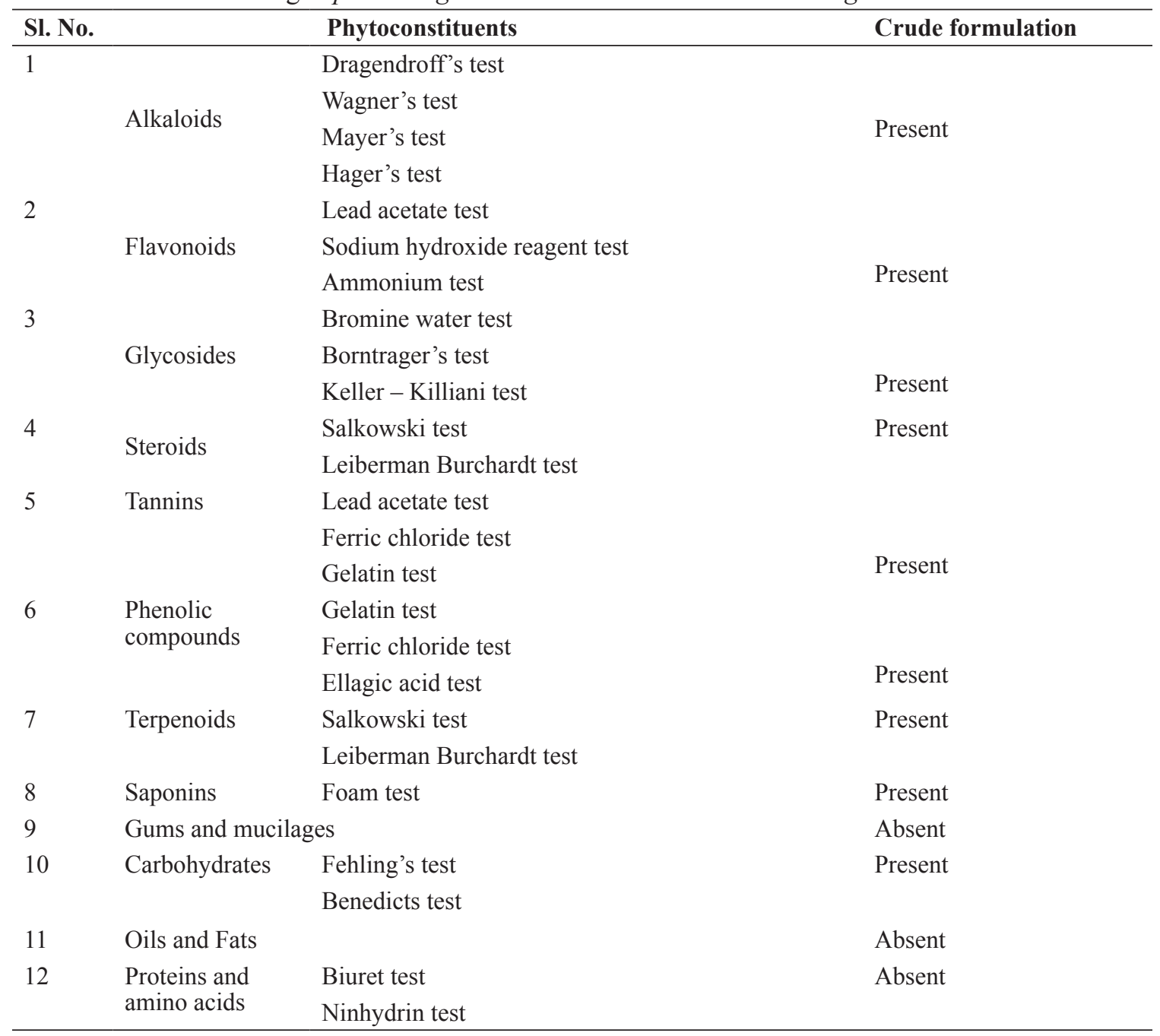

The hot plate method indicated the central analgesic effect of the methanolic extract of the herbal formulation containing leaves of Diploclisia glaucescens and rhizomes of Curcuma longa was significant and dose dependent as revealed by the increased reaction time after giving the thermal stimulus to rats. The latency in the reaction time was continued up to 120 minutes after the administration of test drugs 
at the dose of 200 and $400 \mathrm{mg} / \mathrm{kg}$ body wt orally and the extract revealed sustained and pronounced central analgesic activity. However, the analgesic activity was little lower as compared to standard drug, Ibuprofen respectively. The herbal extracts showed a significant differences on comparision with the control and standard treated groups, but the dosage groups of 200 and $400 \mathrm{mg} / \mathrm{kg}$ body wt. does not have any significance, even at the lower dosages the extract exhibited central analgesic activity respectively (Table 3) $)^{(68,69)}$.

Table 2: List of secondary metabolites and their medicinal values

\begin{tabular}{|c|c|}
\hline Phytoconstituents & Medicinal properties \\
\hline Alkaloids & $\begin{array}{l}\text { Anti-microbial, sedative, relaxant, anti-spasmodic; used to treat tumors, nocturnal leg } \\
\text { cramps, diarrhoea, psychiatric and palpitation }{ }^{(54)}\end{array}$ \\
\hline Flavonoids & $\begin{array}{l}\text { Anti-oxidant, strengthens capillary walls, reduces osteoporosis, improves blood } \\
\text { cholesterol levels, and lowers risk of cancer and coronary heart diseases }{ }^{(55-57)}\end{array}$ \\
\hline Steroids & Aphrodisiac, reduces cholesterol levels, affects immune system and tumor cells ${ }^{(58-60)}$ \\
\hline Terpenoids & $\begin{array}{l}\text { Anti-viral, anti-bacterial, anti-malarial, anti-inflammatory, anti-cancer; inhibits } \\
\text { cholesterol synthesis }\end{array}$ \\
\hline Saponins & $\begin{array}{l}\text { Anti-inflammatory, anti-hepatotoxic, hypoglycemic, anti-microbial and anti-viral; used in } \\
\text { detergents and molluscicides }{ }^{(62,63)}\end{array}$ \\
\hline Tannins & Anti-fungal, anti-biotic, anti-inflammatory, analgesic, astringent and wound healing ${ }^{(64,65)}$ \\
\hline Phenols & Anti-inflammatory, anti-oxidants, anti-cancer, anti-septic ${ }^{(66,67)}$ \\
\hline Glycosides & Sedative, muscle relaxant, diuretic ${ }^{(58)}$ \\
\hline
\end{tabular}

Table 3: Analgesic activity of Herbal formulation (HF-1) in Eddy's Hot Plate model in Wistar albino rats

\begin{tabular}{cccccccc}
\hline \multirow{2}{*}{$\begin{array}{c}\text { Sl } \\
\text { No. }\end{array}$} & Groups & Dose (mg/ & \multicolumn{5}{c}{ Reaction time in seconds } \\
\cline { 4 - 7 } & & $\mathbf{k g})$ & $\mathbf{0} \mathbf{~ m i n}$ & $\mathbf{3 0} \mathbf{~ m i n}$ & $\mathbf{6 0} \mathbf{~ m i n}$ & $\mathbf{9 0} \mathbf{~ m i n}$ & $\mathbf{1 2 0} \mathbf{~ m i n}$ \\
\hline 1 & Control & $10 \mathrm{ml} / \mathrm{kg} \mathrm{DW}$ & $6.28 \pm 0.10$ & $6.44 \pm 0.16^{\mathrm{c}}$ & $6.33 \pm 0.14^{\mathrm{c}}$ & $6.44 \pm 0.16^{\mathrm{c}}$ & $6.36 \pm 0.11^{\mathrm{c}}$ \\
2 & Ibuprofen & $100 \mathrm{mg} / \mathrm{kg}$ & $6.22 \pm 0.10^{\mathrm{C}}$ & $11.0 \pm 0.62^{\mathrm{aB}}$ & $18.43 \pm 0.93^{\mathrm{aA}}$ & $18.1 \pm 0.86^{\mathrm{aA}}$ & $18.00 \pm 0.84^{\mathrm{aA}}$ \\
3 & HF1 & $200 \mathrm{mg} / \mathrm{kg}$ & $6.50 \pm 0.16^{\mathrm{B}}$ & $8.90 \pm 0.42^{\mathrm{bAB}}$ & $11.80 \pm 0.95^{\mathrm{bA}}$ & $11.6 \pm 0.93^{\mathrm{bA}}$ & $11.47 \pm 0.92^{\mathrm{bA}}$ \\
4 & HF1 & $400 \mathrm{mg} / \mathrm{kg}$ & $6.32 \pm 0.18^{\mathrm{C}}$ & $8.7 \pm 0.21^{\mathrm{bB}}$ & $13.61 \pm 0.40^{\mathrm{bA}}$ & $13.5 \pm 0.4^{\mathrm{bA}}$ & $11.31 \pm 0.4^{\mathrm{bA}}$ \\
\hline
\end{tabular}

Values are expressed as Mean \pm SEM, $n=6$ in each group, HF- Herbal Formulation

Means with different superscripts $\left({ }^{a}, b, c\right)$ are statistically $(p<0.05)$ significant between the groups within the reaction time (in seconds) parameter.

Means with different superscripts $(A, B, C)$ are statistically $(p<0.05)$ significant within the groups between the variable reaction time (in seconds) parameter.

The circumference of paw volume measurement was depicted in table 04 respectively. The development of edema in the paw of the rat after injection of formalin is a biphasic event. Inflammation induced by formaldehyde is biphasic, an early neurogeniccomponent is mediated by substance P and bradykinin followed by a tissue mediated response wherehistamine, 5-HT, prostaglandins and bradykin in are known to be involved ${ }^{(70)}$. The initial phase of the edema is due to the release of histamine and serotonin and the edema is maintained during the plateau phase by kinin like substance ${ }^{(71)}$ and the second accelerating phase of swelling due to the release of prostaglandin like substances. Hence, it is speculated that apart from inhibition of chemical mediators of inflammation, poly-herbal formulation may also modulate the 
pain response in the central nervous system. There was a significant dose-dependent inhibition in both phases of the formalin-induced pain response in rats, with a more potent effect in the second phase. Indomethacin also inhibited pain in both phases significantly compared to control and herbal formulation at low and high doses.

Table 4: Analgesic activity of Herbal formulation (HF-1) in Formalin induced paw edema model in Wistar albino rats

\begin{tabular}{ccccccc}
\hline $\begin{array}{c}\text { Sl } \\
\text { No. }\end{array}$ & Groups & Dose (mg/kg) & \multicolumn{2}{c}{ No. of Licking / Biting } & \multicolumn{2}{c}{$\begin{array}{c}\text { Duration of Paw licking / } \\
\text { Biting }\end{array}$} \\
\cline { 3 - 6 } & & & $\mathbf{0 - 5}$ min & $\mathbf{2 0 - 3 0 ~} \mathbf{~ m i n}$ & $\mathbf{0 - 5}$ min & $\mathbf{2 0 - 3 0 ~ m i n}$ \\
\hline 1 & Control & $0.1 \mathrm{ml}$ of 3\% Formalin & $15.17 \pm 0.74^{\mathrm{a}}$ & $25.83 \pm 0.94^{\mathrm{a}}$ & $93.50 \pm 1.43^{\mathrm{a}}$ & $115.33 \pm 2.95^{\mathrm{a}}$ \\
2 & Indomethacin & $10 \mathrm{mg} / \mathrm{kg}$ & $6.83 \pm 0.60^{\mathrm{d}}$ & $14.5 \pm 0.92^{\mathrm{d}}$ & $22.67 \pm 1.49^{\mathrm{d}}$ & $57.50 \pm 1.31^{\mathrm{d}}$ \\
3 & HF1 & $200 \mathrm{mg} / \mathrm{kg}$ & $13.0 \pm 0.63^{\mathrm{b}}$ & $20.67 \pm 0.67^{\mathrm{b}}$ & $73.00 \pm 1.43^{\mathrm{b}}$ & $81.50 \pm 1.50^{\mathrm{b}}$ \\
4 & HF1 & $400 \mathrm{mg} / \mathrm{kg}$ & $10.67 \pm 0.33^{\mathrm{c}}$ & $17.17 \pm 0.91^{\mathrm{c}}$ & $52.00 \pm 2.23^{\mathrm{c}}$ & $72.50 \pm 2.88^{\mathrm{c}}$ \\
\hline
\end{tabular}

Values are expressed in Mean \pm SEM, $n=6$ in each group, HF- Herbal Formulation

Means with different superscripts $\left({ }^{\mathrm{a}, \mathrm{b}, \mathrm{c}}\right)$ are statistically $(\mathrm{p}<0.05)$ highly significant between the groups in the single reaction time (in seconds) parameter.

Table 5: Anti-inflammatory effect in Carrageenan induced paw edema in rats

\begin{tabular}{|c|c|c|c|c|c|c|c|c|c|c|}
\hline \multirow{2}{*}{$\begin{array}{l}\text { Sl } \\
\text { No. }\end{array}$} & \multirow[t]{2}{*}{ Groups } & \multirow{2}{*}{$\begin{array}{l}\text { Dose (mg/ } \\
\text { kg) }\end{array}$} & \multicolumn{8}{|c|}{ Reaction time in seconds } \\
\hline & & & 0 hr & $1 \mathrm{hr}$ & $2 \mathrm{hr}$ & $3 \mathbf{h r}$ & $4 \mathrm{hr}$ & $5 \mathrm{hr}$ & $6 \mathrm{hr}$ & $24 \mathrm{hr}$ \\
\hline 1 & Con & $\begin{array}{l}0.1 \mathrm{ml} \text { of } 1 \% \\
\text { Carrageenan }\end{array}$ & $\begin{array}{l}3.20 \pm \\
0.11^{\mathrm{C}}\end{array}$ & $\begin{array}{c}6.67 \pm \\
0.12^{\mathrm{A}}\end{array}$ & $\begin{array}{c}6.79 \pm \\
0.09^{\mathrm{A}}\end{array}$ & $\begin{array}{c}6.90 \pm \\
0.08^{\mathrm{A}}\end{array}$ & $\begin{array}{l}6.80 \pm \\
0.04^{\mathrm{A}}\end{array}$ & $\begin{array}{l}6.72 \pm \\
0.04^{\mathrm{A}}\end{array}$ & $\begin{array}{l}6.61 \pm \\
0.07^{\mathrm{Aa}}\end{array}$ & $\begin{array}{l}6.10 \pm \\
0.07^{\mathrm{Ba}}\end{array}$ \\
\hline 2 & Ibuprofen & $100 \mathrm{mg} / \mathrm{kg}$ & $\begin{array}{l}3.14 \pm \\
0.09^{\mathrm{D}}\end{array}$ & $\begin{array}{l}6.66 \pm \\
0.07^{\mathrm{AB}}\end{array}$ & $\begin{array}{l}6.81 \pm \\
0.05^{\mathrm{AB}}\end{array}$ & $\begin{array}{l}7.00 \pm \\
0.06^{\mathrm{A}}\end{array}$ & $\begin{array}{l}6.65 \pm \\
0.08^{\mathrm{AB}}\end{array}$ & $\begin{array}{l}6.42 \pm \\
0.09^{\mathrm{AB}}\end{array}$ & $\begin{array}{l}6.07 \pm \\
0.11^{\mathrm{Bb}}\end{array}$ & $\begin{array}{l}4.71 \pm \\
0.33^{\mathrm{Cb}}\end{array}$ \\
\hline 3 & HF1 & $200 \mathrm{mg} / \mathrm{kg}$ & $\begin{array}{l}3.29 \pm \\
0.06^{\mathrm{C}}\end{array}$ & $\begin{array}{l}6.74 \pm \\
0.15^{\mathrm{A}}\end{array}$ & $\begin{array}{l}6.82 \pm \\
0.13^{\mathrm{A}}\end{array}$ & $\begin{array}{l}6.89 \pm \\
0.09^{\mathrm{A}}\end{array}$ & $\begin{array}{c}6.76 \pm \\
0.07^{\mathrm{A}}\end{array}$ & $\begin{array}{c}6.67 \pm \\
0.07^{\mathrm{A}}\end{array}$ & $\begin{array}{l}6.53 \pm \\
0.08^{\mathrm{Aab}}\end{array}$ & $\begin{array}{l}5.80 \pm \\
0.12^{\mathrm{Ba}}\end{array}$ \\
\hline 4 & HF1 & $400 \mathrm{mg} / \mathrm{kg}$ & $\begin{array}{l}3.20 \pm \\
0.10^{\mathrm{E}}\end{array}$ & $\begin{array}{l}6.84 \pm \\
0.06^{\mathrm{AB}}\end{array}$ & $\begin{array}{c}6.91 \pm \\
0.02^{\mathrm{A}}\end{array}$ & $\begin{array}{l}7.02 \pm \\
0.05^{\mathrm{AB}}\end{array}$ & $\begin{array}{c}6.68 \pm \\
0.10^{\mathrm{A}}\end{array}$ & $\begin{array}{l}6.48 \pm \\
0.08^{\mathrm{BC}}\end{array}$ & $\begin{array}{l}6.26 \pm \\
0.08^{\mathrm{Cab}}\end{array}$ & $\begin{array}{l}5.14 \pm \\
0.02^{\mathrm{Db}}\end{array}$ \\
\hline
\end{tabular}

Values are expressed in Mean \pm SEM, $n=6$ in each group, HF- Herbal Formulation

Means with different superscripts $(a, b, c)$ are statistically $(p<0.05)$ significant between the groups within the reaction time (in seconds) parameter.

Means with different superscripts $(A, B, C)$ are statistically $(p<0.05)$ significant within the groups between the variable reaction time (in seconds) parameter. The inflammation of the paw induced by carrageen an agent, was showed a significant decrease in all the standard and test treated groups respectively. The inhibition of the acute inflammation in rat paws at the doses of 200 and $400 \mathrm{mg} / \mathrm{kg}$ body wt. exhibited an anti-inflammatory activity that became significant $(\mathrm{P}<0.05)$ and was maintained all along the experiment. However, the anti-inflammatory effect of standard drug, Ibuprofen was greater than that of the extract as presented in table $5^{(72)}$.

\section{CONCLUSION}

The detailed scientific evaluation of the pharmacological properties namely analgesic and anti-inflammatory activities of the botanical medicine namely Diploclisia glaucescens leaf and rhizomes of Curcuma longa 
in combination clearly exhibited its therapeutic efficacy which was found to be comparable to that of standard drugs. The test drug was found to be significantly effective and having sustained effects during the study. Many of these effects could be attributed due to the presence of secondary metabolites. However, further detailed study is needed to identify the responsible biochemical marker compound in the test drug

Conflict of Interest: None Declared.

\section{ACKNOWLEDGEMENTS}

Authors are thankful to Kerala state government for providing necessary financial support under state plan project 2016-17 (No. RSP/16-17/VI-10)for this research work.

\section{REFERENCES}

1. URL: http://www.fao.org/agriculture/dairy-gateway/milk-production. Gateway to dairy production and products. Accessed on 12.07.2018.

2. Raszek, M.M., L.L. Guan, G.S. Plastow. 2016. Use of genomic tools to improve cattle health in the context of infectious diseases, Front. Genet. 7: 1-15.

3. Holland, J.K., Hadrich, J.C., Wolf, C.A. and Lombard, J. 2015. Economics of Measuring Costs Due to Mastitis-Related Milk Loss. Selected paper prepared for presentation at the 2015 AAEA\& WAEA Joint Annual Meeting, San Francisco, California, July 26-28.

4. Mir, A.Q. et al., 2014. Subclinical mastitis in machine milked dairy farms in Punjab: prevalence, distribution of bacteria and current antibiogram, Vet. World, 7: 291-294.

5. Wellenberg, G.J. W.H.M. Van Der Poel, J.T. Van Oirschot. 2002. Viral infections and bovine mastitis: a review, Vet. Microbiol. 02: 00098-6.

6. Huang, J.M. et al. 2014. Identification of CD14 transcript in blood polymorphonuclear neutrophil leukocytes and functional variation in Holsteins, Genet. Mol. Res. 15.

7. D. Bardhan. 2013. Estimates of economic losses due to clinical mastitis in organized dairy farms," Indian Journal of Dairy Science, 66(2): 168-172.

8. Mathew, L. and Menon, D.G. 2008. Economic impact of FMD in Chazhoor Panchayath. Veterinary World, 1(1): 5-6.

9. Acharya Balkrishnal, Hemanth Kumar M., Deeksha Kumari., Himanshi Kumari and Ashish Kumar Gupta. 2016. Isolation, screening of Mastitis causing bacteria and Antibacterial effect of Poly herbal formulation. International Journal of Recent Scientific Research, 7(5): 11440-11444.

10. Heikkila, A., Nousiainen, J. \& Pyorala, S. 2012. Costs of clinical mastitis with special reference to premature culling. Journal of Dairy Science, 95: 139-150.

11. Mukesh Kr. Sinha, N. N. Thombare and Biswajit Mondal. 2014. Subclinical Mastitis in Dairy Animals: Incidence, Economics, and Predisposing Factors. Scientific World Journal. Article ID 523984, 1-4. 
12. Jadhav, R.K., Singh, V.K. and Bhosale, R.A. 2010. Review of treatment strategies for successful management of bovine mastitis. https://www.researchgate.net/publication/205967616

13. León-Galván, M.F. et al. 2015. Molecular detection and sensitivity to antibiotics and bacteriocins of pathogens isolated from bovine mastitis in family dairy herds of central Mexico, Biomed. Res. Int. 1-9.

14. Saleem Mushtaqa, B., Aabid Manzoor Shaha, Aiyatullah Shaha, Sajad Ahmad Lonea, Aehtesham Hussaina, Qazi Parvaiz Hassana, Md Niamat Ali. 2018. Bovine mastitis: An appraisal of its alternative herbal cure. Microbial Pathogenesis, 114: 357-361.

15. Candace Pollock. 2014. Herbal Treatments Effective in Treating or Preventing Mastitis in Dairy Cattle. Grants and Education to advance innovations in Sustainable Agriculture. Southern SARE (Sustainable Agriculture Research and Education). http://indiabiodiversity.org/species/show/229564

16. Jayasinghe ULB, Wannigama GP, Balasubramaniam S, Habib Nasir and Atta Ur Rahman. 1992. Benzyl iso Quinoline alkaloids from Anamirta cocculus and Diploclisia glaucescens. J of Natn Sci. Count. Srilanka. 20(2): 187-190.

17. Jayasinghe ULB, Fujimoto Y. 2005. Search for biologically active compounds from Sri Lankan Plants. Frontiers in Natural Products Chemistry, 1: 193-199.

18. Immanuel Sagayaraj, M., S. John Britto, M. Thamacin Arulappan, J. Krishnakumar, Sinjumol Thomas and Mariat George. 2014. Antimicrobial studies and phytochemical screening of the leaves in Tiliacoraa cuminata (lam.) hook. \& Thomson and Diploclisia glaucescens (blume) diels. (Menispermaceae). Asian J. Pharm. Res. 4(2): 82-86.

19. Krup V, Prakash LH, Harini A. 2013. Pharmacological Activities of Turmeric (Curcuma longa linn): A Review. J HomeopAyurv Med., 2:133. .

20. Sastry JLN. 2005. Illustrated Dravyaguna Vijnana. ( $2^{\text {nd }}$ edn), Chaukhambha Orientalia, Varanasi, India 513-518.

21. Ott, S. 1999. Costs of herd-level production losses associated with subclinical mastitis in US dairy cows, Proceedings of the $38^{\text {th }}$ Annual Mtg. National Mastitis Council, Arlington VA, Natl. Mast. Counc., Madison WI, 152-156.

22. Sharma PV. 2006. Dravya Guna Vijnana, Chaukhambha Bharti Academy, Varanasi, India 1: 162-166.

23. Chunekar KC 2010. Editor Bhavpraakash Nighantu of Bhava Misra. Chaukhambha Bharti Academy, Varanasi: 110.

24. Pandey GS. 2002. Dravyaguna Vijnana ( $\left.2^{\text {nd }} e d n\right)$, Krishnadas Academy, Varanasi, India 1: 737-746.

25. Viguier, C. et al. 2009. Mastitis detection: current trends and future perspectives, Trends Biotechnol. 27: 486-493.

26. Paranjpe P. 2001. Herbs for Beauty. (1stedn), Chaukhambha Sanskrit Pratishthan, Delhi, India 95-96.

27. Anokwuru, C.P, Anyasor, G.N., Ajibaye O., Fakoya O., Okebugwu P. 2011. Effect of Extraction Solvents on Phenolic, Flavonoid and Antioxidant activities of Three Nigerian Medicinal Plants. Nature and Science; 9(7): 53-61. 
28. Anokwuru, C.P, Anyasor, G.N., Ajibaye O., Fakoya O., Okebugwu P. 2011. Effect of Extraction Solvents on Phenolic, Flavonoid and Antioxidant activities of Three Nigerian Medicinal Plants. Nature and Science; 9(7). 53-61.

29. Harborne, 1998. Phytochemical Methods Chapman Hall, London. pp 60-66.

30. Ranjith D and Maria L. 2017. A Review on Phytochemicals Based Extraction and their Qualitative Screening Protocols. Indian Journal of Natural Sciences. 8(44): 12794 - 12804.

31. Muhammad Naveed, Muhammad Saeed and Haroon Khan. 2012. Antipyretic, analgesic and antiinflammatory activity of Viola betonicifolia whole plant. BMC Complementary and Alternative Medicine. 12: $59.1-8$.

32. Nikajoo LT. 2009. Analgesic activity of Aqueous and Alcohol root extracts of Pergularia daemia (forsk.) Chiov. International Journal of Pharmacy and Pharmaceutical. Sciences, 1(1). 2009.

33. Kulkarni SK. 1999. Handbook of Experimental Pharmacology. 3rd rev. Ed. New Delhi: Vallabh Prakashan. 123-25.

34. Pravin V. Gomase, Priti S. Shire, Sayyed Nazim and Amol B. Choudhari. 2011. Development and Evaluation of analgesic polyherbal formulation containing some indigenous medicinal plants. International Journal of Pharma and Bio Sciences. 2(3): 119-P127.

35. Ellis A., N. Benson, I. Machin, and L. Corradini. 2008. The rat formalin test: Can it predict neuropathic pain treatments? Proceedings of Measuring Behavior 2008 (Maastricht, The Netherlands, August 26-29, 2008).

36. Chakraborty R, Devi KB, Reta S, Sharatchandra K, Singh TI. 2004. Preliminary studies on antiinflammatory and analgesic activities of Spilanthes acmella in experimental animal models. Ind $J$ Pharmacol., 36: 148-150.

37. Lakshmi B, Ajith TA, Sheena N, Gunapalan N, Janardhanan KK. 2003. Antiperoxidative, anti-inflammatory and antimutagenic activities of ethanol extract of the Mycelium of Genoderma lucidum occurring in south India. Teratogen carcinogen Mutagen Suppl. 1: 85-97.

38. Winter CA, Risley EA, Nuss GW. 2007. Analgesic activity of extract of Phyllanthus reticulantus. Proc SocExpBiol Med. 112: 162-165

39. Saha A, Masud MA, Bachar SC, Kundu JK, Datta BK, Nahar L, Sarker SD. 2007. The analgesic and antiinflammatory activities of extracts of Phyllanthus reticulantus in mice model. Pharm Boil, 25: 355-359.

40. Lakshman SH, Kar N, Maurya V, Viswanatha GL. 2008. Analgesic and anti-inflammatory activity of topical preparation of Lantancamara leaves. Pharmacol Online, 1: 90-96.

41. Okokon JE, Bassey SA, Umoh E. 2008. Analgesic and anti-inflammatory effects of ethanolic extracts of Hippocratiaafricana. Int J Pharmacol. 4: 51- 55.

42. Guay J, Bateman K, Gordon R, Mancini J, Riendeau D. 2004. Carrageenan induced paw edema in rats elicits a predominant prostaglandin $\mathrm{E}_{2}$ (PGE-2) response in the central nervous system associated with the induction of microsomal PGE-2 synthase-1. T Biol Chem. 279: 24866-24872. 
43. Ghada-Maria S, Abbott FV. 2000. The formalin test in the mouse: a prametric analysis of scoring properties. Pain. 89: 53-63.

44. Rajasekharan, P.E. and S. Ganeshan. 2002. Conservation of Medicinal Plant Biodiversity-An Indian Perspective. Journal of Medicinal and Aromatic Plant Sciences, 132.

45. Darrell Posey. 1990. Intellectual Property Rights: And Just Compensation for Indigenous Knowledge. Anthropology Today 13.

46. Lokesha P. and Vasudeva, R. 1997. Pattern of Life History Traits Amoung Rare/Endangered Plants of South India" 73 Current Science 171.

47. Ruby Tiwari, Rana, C.S. 2015. Plant secondary metabolites: a review. International Journal of Engineering Research and General Science, 3(5): 661-670.

48. Rajesh, H, Rao, S.N, Megha Rani. N, Prathima, K. Shetty, Rejeesh E.P, Chandrashekar R. Phytochemical analysis of methanolic extract of Curcuma longa linn rhizome. International journal of Universal Pharmacy and Bio sciences, 2(2). 39-45.

49. Chairman M, Jayamala M, Christy VR, Singh, RAJA 2015. Phytochemical Screening and Antimicrobial Activity of Curcuma longa Natural Dye. Gen Med (Los Angel) 3:171.

50. Arutselvi, R., Balasaravanan, T., Ponmurugan, P., Muthu Saranji, N. and Suresh, P. 2012. Phytochemical screening and comparative study of anti microbial activity of leaves and rhizomes of turmeric varieties. Asian Journal of Plant Science and Research, 2(2): 212-219.

51. Sawant, R.S. and Godghate, A.G. 2013. Qualitative phytochemical screening of rhizomes of Curcuma longa linn. International Journal of Science, Environment and Technology, 2(4): 634 - 641.

52. Immanuel Sagayaraj M, S. John Britto, M. Thamacin Arulappan, J. Krishnakumar, Sinjumol Thomas and Mariat George. 2014. Antimicrobial studies and phytochemical screening of the leaves in Tiliacoraacuminata (lam.) hook. \& Thomson and Diploclisia glaucescens (blume) diels. (menispermaceae). Asian Journal of Pharmaceutical Research. 4(2): 82-86.

53. Myers, N., Mittermeir, R.A., Mittermeir, C.G., Fonseca, G.A.B. and Kent, J. 2000. "Biodiversity Hotspot for Conservation Priorities" 403 Nature 853.

54. Visweswari G, Christopher R and Rajendra W. 2013. Phytochemical screening of active secondary metabolites present in Withania somnifera root: Role in traditional medicine. Int J Pharm Sci Res., 4(7): 2770-2776.

55. Middleton E. Jr: 1998. Effect of plant flavonoids on immune and inflammatory cell function. Advances in Experimental Medicine and Biology, 439: 175-182.

56. Amalesh Samanta, Gouranga Das, Sanjoy Kumar Das: 2011. Roles of Flavonoids in Plants. International Journal of Pharmaceutical Science and Technology, 6: 12-35.

57. Singh G. and Kumar P. 2011. Evaluation of antimicrobial efficacy of flavonoids of Withania somnifera L. Indian Journal of Pharmaceutical Sciences, 73: 473-478. 
58. Veena Sharma, Sadhana Sharma, Pracheta, Ritu Paliwal 2011. Withania somnifera: A rejuvenating ayurvedic medicinal herb for the treatment of various human ailments. International Journal of Pharmatech Research, 3: 187-192.

59. Amalesh Samanta, Gouranga Das, Sanjoy Kumar Das. 2011. Roles of Flavonoids in Plants. International Journal of Pharmaceutical Science and Technology, 6: 12-35.

60. Singh G and Kumar P. 2011. Evaluation of antimicrobial efficacy of flavonoids of Withania somnifera L. Indian journal of Pharmaceutical Sciences, 73: 473-478.

61. Mahato SB and Sen S. 1997. Advances in terpenoid research 1990-1994. Phytochemistry, 44: 1185-1236.

62. EFSA 2009. http://www.efsa.europa.eu/en/efsajournal/pub/979.html.

63. Shi J, Arunasalam K, Yeung D, Kakuda Y, Mittal G, Jiang Y. 2004. Saponins from edible legumes: Chemistry, processing and health benefits. Journal of Medicinal Food, 7: 67-78.

64. Chung KT, Wong TY, Wei CL, Huang YW, Lin Y. 1998. Tannins and human health: A review. Critical Reviews in Food Science and Nutrition, 6: 421-464.

65. Okwu, DE, Josiah C. 2006. Evaluation of the chemical composition of two Nigerian medicinal plants. African Journal of Biotechnology, 5: 357-361.

66. Lattanziovincenzo, Veronica MT, Lattanzio, Angela Cardinali. 2006. Role of phenolics in the resistance mechanisms of plants against fungal pathogens and insects Phytochemistry. Advances in Research, 23-67.

67. Michalak A. 2006. Phenolic compounds and their antioxidant activity in plant growing under heavy metal stress. Polish Journal of Environmental Studies, 15: 523-530.

68. Mangesh S. Bansod, Virendra G. Kagathara and Ashwin D. Somkuwar. 2010. Evaluation of Analgesics and Anti-inflammatory Activity of a Poly-Herbal Formulation. International Journal of PharmTech Research, 2(2): 1520-1527.

69. Jayanthi MK, Jyoti MB. 2012. Experimental animal studies on analgesic and anti-nociceptive activity of Allium sativum (Garlic) powder. IJRRMS. 2(1): 1-6.

70. Wheeler-Aceto H. and Cowan A. 1991. Neurogenic and tissue mediated components of formalin-induced edema: evidence for supraspinal regulation, Agents Action., 34: 264-269.

71. Chauhan O., Godhwani J.L., Khanna N.K. and Pendse V.K. 1998. Antiinflammatory activity of muktashuktibhasma, Indian J. Exp. Biol., 36: 985-989.

72. Joshi punam, Priyabhanu and Gahlotmanoj. 2014. Anti-inflammatory and analgesic activities of methanol extract of Vallarissolanacea leaves, 6(2): 622-624. 